\title{
Development of foam mat dried soursop powder using arabic gum and fish gelatin as foaming agent
}

\author{
${ }^{1}$ Vasudevan, N., ${ }^{1,2 *}$ Sulaiman, R., ${ }^{1}$ Chong, G.H., ${ }^{1}$ Adzahan, N.A. and ${ }^{2}$ Shaari, N.A. \\ ${ }^{1}$ Department of Food Technology, Faculty of Food Science and Technology, Universiti Putra Malaysia, \\ 43400 Serdang, Selangor Darul Ehsan, Malaysia. \\ ${ }^{2}$ Halal Products Research Institute, Universiti Putra Malaysia, 43400 Serdang, Selangor Darul Ehsan, \\ Malaysia.
}

\begin{abstract}
Article history:
Received: 20 August 2019

Received in revised form: 8

November 2019

Accepted: 14 December 2019

Available Online: 10

February 2020
\end{abstract}

Keywords:

Annona muricata,

Foam mat drying,

Foaming agent,

Fish gelatin,

Arabic gum

DOI:

https://doi.org/10.26656/fr.2017.4(S1).S16

\begin{abstract}
Soursop is also known as Annona muricata from Annonaceae family. Soursop flavour has been described as a combination of strawberry and pineapple, with sour citrus flavor. The foam mat drying is a process in which the transformation of products from liquid to stable foam followed by air drying. The foam mat drying process is reported to be considerably cheaper than vacuum, freeze and spray drying methods. Foam mat drying was done using different foaming agents at various concentration: fish gelatin (FG: 5, 10, 15, 20\%) and arabic gum (AG: 2, 4, 6, 8\%). Foam properties and physicochemical properties such as bulk density, tap density, $\mathrm{pH}$, moisture content, water activity, total phenolic content, color and flowability of powder were analyzed. Increasing the concentration of foaming agents showed a decreasing trend of the total phenolic contents and the value ranges from 222 to $453 \mathrm{mg} \mathrm{GAE} / 100 \mathrm{~g}$. Soursop powder with fish gelatin has higher total phenolic content compared to sample with Arabic gum. Soursop powder with both foaming agents showed an excellent flowability.
\end{abstract}

\section{Introduction}

Soursop is also known as Annona Muricata from the family of Annonaceae is an evergreen plant which is native to the warmest tropical areas in South and North America and is now widely distributed throughout tropical and subtropical parts of the world, including India, Malaysia and Nigeria (Adewole and CaxtonMartins, 2006). Soursop fruit also can be called as Graviola and guanabana. According to Baskar et al. (2007), all parts of soursop fruit are used in traditional folk medicine as it considered as good source of antioxidants. Soursop has a short shelf life because the fruit ripens faster. To extend the shelf life of the fruit, an alternative method to preserve the fruit need to be taken and drying is a suitable method to preserve the fruit.

Drying is an important process to preserve raw food materials. The drying process occurs when water vapor is removed from its surface into the surrounding space, resulting in a dried material with an extended shelf life and reduced water activity of food products. During drying, the moisture content can be reduced to a level ranging from 1 to $5 \%$, which avoids microbial spoilage and undesirable enzymatic reactions. In addition to a substantial reduction in weight and volume, it minimizes packaging, storage and transportation costs (Fumagalli and Silveira 2005; Falade and Solademi 2010). Foammat drying is a process of drying liquid-solid foods by being mixed with a stabilizing agent and or foaming agent to produce a stable foam, which undergoes hot air drying temperatures ranging from $50-80^{\circ} \mathrm{C}$ (Kandasamy et al., 2012; Febrianto et al., 2012). Mixtures are whipped to form stable foams using blender or specially designed device. The foam is then spread as a thin sheet or mat and exposed to the stream of hot air until it is dried to the desired moisture content (Sangamithra et al., 2014). The foam dried product is then further ground to produce a powdered product. Foam mat drying can be done for viscous foods, heat sensitive and high sugar content which is difficult-to-dry and sticky under relatively mild conditions without quality change (Morgan et al., 1961). This proves that this method is suitable for drying of viscous, sticky and heat sensitive products. Stable gas-liquid foam is the primary condition for successful foam drying. Proteins, gums and various emulsifiers (glycerol monostearate, propylene glycerol monostearate, carboxymethyl cellulose, trichlorophosphate) are used as foaming agents. Fish gelatin, egg albumin, arabic gum, and methylcellulose are in which commonly used in foam mat drying process. The advantages of the foam mat drying process include 
suitability for all types of juices, rapid drying at a lower temperature, retention of nutritional quality, easy reconstitution and cost-effective for producing easily reconstitutable juice powders (Kudra and Ratti, 2006).

This process can be used for large scale production of fruit powders because of its suitability for all types of juices, rapid drying at a lower temperature, retention of nutritional quality, easy reconstitution and cost-effective for producing easily reconstitutable juice powders. Fruit juice powders obtained through foam mat drying process have high economic potentials over their liquid counterparts such as reduced volume or weight, reduced storage space, simpler handling and transportation, and much longer shelf life. Fish gelatin is a type of protein which gives a good foamability and high foam stability through their hydrophobicity and possible conformational rearrangements, which allow rapid adsorption at the air-water interface leading to the formation of a coherent elastic adsorbed layer (Dickinson, 1992). Arabic gum is used as foaming agent which enhances the stability of the foam emulsion. The use of fish gelatin and Arabic gum in this study could help in halal product development by replacing the use of mammalian gelatin and other non-halal ingredients. In this research, fish gelatin and Arabic gum at different concentrations were used to study the effect of foaming agents on producing soursop powder. The fruit powders obtained through this method can find applications in snacks, beverages, ice creams, bakery products, as a starter for the preparation of instant foods and pastes (Sangamithra et al., 2014).

\section{Materials and methods}

\subsection{Raw material}

Soursop was purchased from Pasar Borong, Selangor. The commercial maturity of soursop was selected based on the uniformity of the green color of the fruit skin and the firmness surface of soursop. Fish gelatin (240-260 bloom) was obtained from Custom collagen, US and Arabic gum were purchased from Markaids (Malaysia) Sdn Bhd.

\subsection{Foam mat drying}

The soursop fruit was peeled, unseeded and cut into $2 \mathrm{~cm}$ cubic size. Then, the fruit was washed and the excess water from the washing process is filtered. The washed fruit was blanched for 5 mins. After blanching, the soursop fruit was put into the food processor to blend the fruit. After the soursop puree was obtained, foaming agent (fish gelatin: 5, 10, 15 and 20\% wt/wt; Arabic gum: 2, 4, 6 and $8 \% \mathrm{wt} / \mathrm{wt}$ ) was added to the puree. The percentage of arabic gum and fish gelatin differ because the maximum amount of arabic gum can be used as additives is $9 \%$ in food product (Mortensen et al., 2017) and there is no fix value for fish gelatin as it is considered as protein. The mixture was whipped using food processor (MK-5087M Panasonic, Malaysia) at speed 1 for 10 mins for the foam to form. After whipping process was done, the sample was layered on a tray approximately about $1 \mathrm{~cm}$ thickness and kept the tray into the cabinet dryer at $50^{\circ} \mathrm{C}$ for drying until the moisture content reached below $5 \%$ wet basis.

\subsection{Foam properties}

\subsubsection{Foam density}

The soursop foam was poured into a measuring cylinder without trapping the air voids and also without breaking down the foam structure. The weight and volume of the foam were recorded. Foam density was calculated using equation:

$$
\text { Foam Density }=\frac{\text { Weight of Foam }(\mathrm{g})}{\text { Volume of Foam }\left(\mathrm{cm}^{3}\right)}
$$

\subsubsection{Foam expansion}

Foam expansion indicates the amount of air incorporated into the whipped mixture. Foam expansion was calculated using the differences in the weight of the pulp before and the after foaming as described:

$$
\text { Foam expansion }(\%)=\frac{\left(\mathrm{V}_{1}-\mathrm{V}_{0}\right)}{\mathrm{V}_{\mathrm{n}}} \times 100
$$

Where $V_{o}$ is the initial volume of the pulp $\left(\mathrm{cm}^{3}\right)$ and the $\mathrm{V}_{1}$ is the volume of the pulp after foaming $\left(\mathrm{cm}^{3}\right)$.

\subsection{Physicochemical properties}

\subsubsection{Moisture content}

The moisture content of the sample was determined by using moisture analyzer (Precisa XM 120 Halogen/50 $\mathrm{Hz}$ ). About $1.0 \mathrm{~g}$ of sample was used for the analysis and were analyzed in triplicates.

\subsubsection{Water activity}

The water activity $\left(\mathrm{a}_{\mathrm{w}}\right)$ of soursop powder was measured using water activity analyzer (Aqua Lab). The water activity analyzer was calibrated using distilled water before the analysis of the sample was done. Each sample was analyzed in triplicates and the mean value was calculated.

\section{$2.4 .3 \mathrm{pH}$}

Digital pH meter (Jenway $3505 \mathrm{pH}$ meter) was used to measure the $\mathrm{pH}$ of juice made by soursop powder. Before using the $\mathrm{pH}$ meter, the $\mathrm{pH}$ meter was calibrated using buffer solution ( $\mathrm{pH} 4$ and $\mathrm{pH}$ 7). Each sample was analyzed in triplicates and the mean value was calculated. 


\subsubsection{Color}

The color of soursop powder was determined by using color analyzer (Chromameter Minolta CR-300). Each sample was analyzed in triplicates and the mean value was calculated.

\subsubsection{Bulk density}

The density of the soursop powder was calculated by using following equation:

$$
\text { Bulk density }=\frac{\text { Mass of the powder }(\mathrm{g})}{\text { Volume of the powder }\left(\mathrm{cm}^{3}\right)}
$$

\subsubsection{Tap density}

The tap density was measured by pouring approximately $20 \mathrm{~mL}$ of powder into $50 \mathrm{~mL}$ graduated cylinder and tapping the cylinder until a final constant volume was achieved. The density was evaluated manually. The mass and the constant volume of the powder were recorded. The tap density was calculated using the following equation:

Tap density $=\frac{\text { Weight of the powder }(\mathrm{g})}{\text { Constant volume of the powder }(\mathrm{ml})}$

\subsubsection{Carr index and Hausner ratio}

Flow property of samples was evaluated by using Carr Index (Carr, 1965) and Hausner Ratio (Hausner, 1967). Carr Index and Hausner Ratio were calculated from bulk density and tapped density.

$$
\begin{aligned}
& \text { Carr Index }(\mathrm{CI})=\frac{\text { Tap density-Bulk density }}{\text { Tapped density }} \times 100 \\
& \text { Hausner Ratio (HR) }=\frac{\text { Tap density }}{\text { Bulk density }}
\end{aligned}
$$

\subsubsection{Total phenolic content}

The polyphenol content of the samples was determined by the Folin-Ciocalteu method (Cemeroglu, 2010). Gallic acid was used as the standard for the preparation of the calibration curve. The powder sample was stirred in $60 \%$ of ethanol solution. The $0.3 \mu \mathrm{L}$ of the extract was mixed with $2.5 \mathrm{~mL}$ of $10 \%$ of FolinCiocalteu reagent addition and incubated at room temperature for $5 \mathrm{~min}$. A total of $2 \mathrm{~mL}$ of $7.5 \% \mathrm{Na}_{2} \mathrm{CO}_{3}$ solution was added to the mix and after $2 \mathrm{hrs}$ of incubation in dark environment, the absorbance values were measured at $760 \mathrm{~nm}$. The results were calculated and expressed as " $\mathrm{mg}$ of gallic acid equivalent per 100 g.

\subsubsection{Water solubility index (WSI) Water absorption index (WAI)}

Approximately $1 \mathrm{~g}$ of the soursop powder was added to $10 \mathrm{~mL}$ of water at room temperature and stirred for 30 mins. Following this, the mixture was centrifuged for 10 mins at $3500 \mathrm{rpm}$. The supernatant was carefully transferred into a crucible and oven-dried overnight at $100^{\circ} \mathrm{C}$. The weight of the solids in the dried supernatant, as a percentage of the total dry solids in the original $1 \mathrm{~g}$ of the sample, provides an indication of the solubility index. The water absorption index was measured by weighing the amount of wet solids remaining after centrifugation. The water solubility index (WSI) and water absorption index (WAI) were calculated using the following equations:

$$
\begin{aligned}
& \text { WSI }(\%)=\frac{\text { Weight of dry solid after centifugation }}{\text { Weight of initial dry sample }} \times 100 \\
& W A I=\frac{\text { Weight of wet solid after centifugation }}{\text { Weight of initial dry sample }}
\end{aligned}
$$

\subsection{Statistical analysis}

Data were analyzed using the Minitab statistical software, version 16 (Minitab Inc., State College, PA, USA. Statistical differences among means were determined by Duncan's multiple range test at 5\% significance level.

\section{Results and discussion}

\subsection{Foam properties}

According to Thuwapanichayanan et al. (2008) and Falade et al. (2003), the more the amount of the air incorporated during whipping, the more the decrease in the density of foam structure that leads to the large surface area of the foam juice and faster evaporation rate during foam mat drying. Table 1 shows that the lowest foam density showed a large value of the foam expansion. Large foam expansion indicates that more air was incorporated into the puree during whipping time. Karim and Wai (1999) reported that foaming agents that migrates from the aqueous phase to the air-liquid interphase has induced the reduction of the surface tension and increase the area. Low foam density and high foam expansion results in low bulk density of the foam mat dried soursop powder.

Table 1. Foam properties of different foaming agents during foam mat drying.

\begin{tabular}{cccc}
\hline $\begin{array}{c}\text { Foaming } \\
\text { agents }\end{array}$ & $\begin{array}{c}\text { Concentration } \\
(\%)\end{array}$ & $\begin{array}{c}\text { Foam density } \\
\left(\mathrm{g} / \mathrm{cm}^{3}\right)\end{array}$ & $\begin{array}{c}\text { Foam Expansion } \\
(\%)\end{array}$ \\
\hline \multirow{3}{*}{ Fish gelatin } & 5 & $1.08 \pm 0.03^{\mathrm{ab}}$ & $6.39 \pm 0.12^{\mathrm{f}}$ \\
& 10 & $0.99 \pm 0.02^{\mathrm{d}}$ & $8.20 \pm 0.52^{\mathrm{e}}$ \\
& 20 & $0.95 \pm 0.01^{\mathrm{de}}$ & $10.66 \pm 0.25^{\mathrm{bc}}$ \\
& 2 & $1.041 \pm 0.01^{\mathrm{bc}}$ & $7.872 \pm 0.23^{\mathrm{e}}$ \\
Arabic gum & 4 & $0.916 \pm 0.02^{\mathrm{ef}}$ & $14.635 \pm 0.09^{\mathrm{a}}$ \\
& 6 & $0.964 \pm 0.01^{\mathrm{de}}$ & $10.358 \pm 0.10^{\mathrm{bc}}$ \\
& 8 & $0.994 \pm 0.00^{\mathrm{cd}}$ & $9.984 \pm 0.50^{\mathrm{cd}}$ \\
\hline
\end{tabular}

Mean values which do not share the same superscript letters are significantly different at $5 \%$ for different concentration of foaming agents. 
3.2 Physicochemical properties of foam mat dried soursop powder.

\subsubsection{Moisture content, water activity, $\mathrm{pH}$}

As in Table 2, the $\mathrm{pH}$ of all the foam-mat dried soursop powders with different types and different concentration of foaming agents are in between 4.00 to 5.00. Thus, the powder has low acidity properties because the soursop fruit has the same properties. The $\mathrm{pH}$ of fresh soursop fruit is 3.70 but the foam-mat dried soursop powders are high in $\mathrm{pH}$ value due to the foaming agents that are added in the making of the powder. However, the $\mathrm{pH}$ of the foam mat dried soursop powder does not affect by the type of foaming agents used in the foam mat drying process.

The moisture content for overall powder is between 4.65 to $6.86 \%$ as shown in Table 2 . These values are similar to low moisture content for commercial products such as soluble coffee $(4.18-5.25 \%)$, tomato $(3.4-4.0 \%)$ and soursop powder. These results showed that there is no probability for the occurrence of chemical reactions and pathogen growth (Jaya and Das, 2004). The reduction in moisture content may be contributed by foaming properties of the sample. Higher foam expansion produces powder with more porous structure, thus accelerating moisture loss of the powder (Abbasi and Azizpour, 2016).

The water activity is described as the 'proportion between the water vapor pressure of the food and the vapor pressure of pure water at similar temperature' according to Berk (2009). A reduction in water activity prevents microbial growth, decline enzymatic response rate and delays Maillard reaction (Belitz et al., 2009). In this research, all the samples showed water activity below 0.40 as shown in Table 2. According to Rao et al. (2005), these values are quite favorable for the stability of the juice in minimizing microbial growth, oxidative and enzymatic reactions.

\subsubsection{Bulk density, tap density}

Bulk density is defined as the mass of solid particles plus moisture divided by the total volume engaged by the particles, surface moisture and all pores are closed or open, in the surrounding atmosphere. Generally, bulk density is used to characterize the final product acquired by milling or drying (Johanson, 2005). Bulk density is a parameter of the powder product which represent for economical and practical reason. From Table 3, sample powder with fish gelatin showed an increase in the bulk density as the concentration increase because fish protein is rich in protein where proteins have a higher molecular weight (Nelson and Cox, 2004). The highest bulk density $0.78 \mathrm{~kg} / \mathrm{m}^{3}$ is powder produced using fish gelatin at $20 \%$.

Tap density is the density that obtained after the powder was tapped manually. As the powder was tapped, the volume of the powder will decrease but the weight of the powder remains constant. Thus, the density will increase and eventually higher compared to bulk density.

Table 2. Moisture content, water activity, $\mathrm{pH}$ of foam mat dried soursop powder

\begin{tabular}{ccccc}
\hline Foaming agents & Concentration (\%) & $\mathrm{pH}$ & Water activity $\left(\mathrm{a}_{\mathrm{w}}\right)$ & Moisture Content $(\%)$ \\
\hline \multirow{4}{*}{ Fish gelatin } & 5 & $4.52 \pm 0.01^{\mathrm{d}}$ & $0.36 \pm 0.00^{\text {cde }}$ & $6.86 \pm 0.01^{\mathrm{c}}$ \\
& 10 & $4.66 \pm 0.01^{\mathrm{c}}$ & $0.37 \pm 0.00^{\mathrm{bcde}}$ & $6.46 \pm 0.01^{\mathrm{b}}$ \\
& 15 & $4.81 \pm 0.01^{\mathrm{b}}$ & $0.36 \pm 0.00^{\mathrm{de}}$ & $4.89 \pm 0.02^{\mathrm{c}}$ \\
\multirow{5}{*}{ Arabic Gum } & 20 & $4.94 \pm 0.01^{\mathrm{a}}$ & $0.39 \pm 0.00^{\mathrm{a}}$ & $5.47 \pm 0.02^{\mathrm{ab}}$ \\
& 2 & $4.34 \pm 0.01^{\mathrm{g}}$ & $0.39 \pm 0.00^{\mathrm{a}}$ & $4.65 \pm 0.01^{\mathrm{f}}$ \\
& 4 & $4.37 \pm 0.00^{\mathrm{f}}$ & $0.37 \pm 0.00^{\mathrm{abc}}$ & $4.87 \pm 0.01^{\mathrm{d}}$ \\
& 6 & $4.38 \pm 0.00^{\mathrm{f}}$ & $0.38 \pm 0.00^{\mathrm{abc}}$ & $4.80 \pm 0.03^{\mathrm{e}}$ \\
\hline
\end{tabular}

Mean values which do not share the same superscript letters are significantly different at $5 \%$ for different concentration of foaming agents.

Table 3. Bulk density and tap density of foam mat dried soursop powders

\begin{tabular}{cccc}
\hline Foaming agents & Concentration $(\%)$ & Bulk density $\left(\mathrm{g} / \mathrm{cm}^{3}\right)$ & Tap density $\left(\mathrm{g} / \mathrm{cm}^{3}\right)$ \\
\hline \multirow{3}{*}{ Fish gelatin } & 5 & $0.71 \pm 0.01^{\mathrm{b}}$ & $0.80 \pm 0.00^{\mathrm{b}}$ \\
& 10 & $0.76 \pm 0.00^{\mathrm{a}}$ & $0.81 \pm 0.01^{\mathrm{b}}$ \\
& 15 & $0.78 \pm 0.01^{\mathrm{a}}$ & $0.86 \pm 0.00^{\mathrm{a}}$ \\
Arabic Gum & 20 & $0.78 \pm 0.00^{\mathrm{a}}$ & $0.88 \pm 0.00^{\mathrm{a}}$ \\
\hline & 2 & $0.70 \pm 0.00^{\mathrm{a}}$ & $0.78 \pm 0.01^{\mathrm{c}}$ \\
& 6 & $0.65 \pm 0.00^{\mathrm{bcd}}$ & $0.70 \pm 0.01^{\mathrm{e}}$ \\
& 8 & $0.68 \pm 0.00^{\mathrm{d}}$ & $0.71 \pm 0.01^{\mathrm{de}}$ \\
\hline
\end{tabular}

Mean values which do not share the same superscript letters are significantly different at $5 \%$ for different concentration of foaming agents. 
Table 4. The flowability of foam mat dried soursop powders.

\begin{tabular}{ccccc}
\hline Foaming agents & Concentration (\%) & Carr Index $(\%)$ & Hausner ratio & Flowability \\
\hline \multirow{3}{*}{ Fish gelatin } & 5 & $11.889 \pm 0.19^{\mathrm{ab}}$ & $1.134 \pm 0.00^{\mathrm{a}}$ & Good \\
& 10 & $5.432 \pm 1.11^{\mathrm{cd}}$ & $1.057 \pm 0.01^{\mathrm{b}}$ & Excellent \\
& 15 & $9.549 \pm 1.15^{\mathrm{abc}}$ & $1.106 \pm 0.01^{\mathrm{ab}}$ & Excellent \\
& 20 & $9.094 \pm 0.01^{\mathrm{bc}}$ & $1.100 \pm 0.00^{\mathrm{ab}}$ & Excellent \\
\hline \multirow{3}{*}{ Arabic Gum } & 2 & $9.333 \pm 1.16^{\mathrm{bc}}$ & $1.103 \pm 0.01^{\mathrm{ab}}$ & Excellent \\
& 4 & $6.793 \pm 1.07^{\mathrm{cd}}$ & $1.060 \pm 0.04^{\mathrm{b}}$ & Excellent \\
& 6 & $4.052 \pm 0.36^{\mathrm{d}}$ & $1.047 \pm 0.01^{\mathrm{b}}$ & Excellent \\
\hline
\end{tabular}

Mean values which do not share the same superscript letters are significantly different at $5 \%$ for different concentration of foaming agents.

The highest tap density was observed for powder which contained $20 \%$ of fish gelatin.

\subsubsection{Flowability}

The Carr index and Hausner ratio are the deciding factors for the powder flowability. These factors have their own ranges of the value to determine the flowability of the powders. As in Table 4, the flowability of the powders for all concentration of different foaming agents was excellent except fish gelatin 5\% which are good in flowability. According to Chang et al. (2009), the powder flowability has the influence of moisture content and water activity. Moisture content and water activity for all the foam-mat dried powders are relatively low, so the flowability of the powders is mostly excellent.

\subsubsection{Total phenolic content}

Table 5. Total phenolic content of foam mat dried soursop powder.

\begin{tabular}{ccc}
\hline $\begin{array}{c}\text { Foaming } \\
\text { agents }\end{array}$ & Concentration (\%) & $\begin{array}{c}\text { Phenolic Content } \\
(\mathrm{mg} \mathrm{GAE} / 100 \mathrm{~g})\end{array}$ \\
\hline \multirow{4}{*}{ Fish gelatin } & 5 & $453.99 \pm 2.04^{\mathrm{ab}}$ \\
& 10 & $417.83 \pm 7.66^{\mathrm{b}}$ \\
& 20 & $267.12 \pm 24.38^{\mathrm{d}}$ \\
Arabic Gum & 2 & $266.15 \pm 18.09^{\mathrm{d}}$ \\
\hline & 6 & $339.23 \pm 15.70^{\mathrm{c}}$ \\
& 8 & $278.75 \pm 5.20^{\mathrm{d}}$ \\
& 6 & $263.38 \pm 10.21^{\mathrm{d}}$ \\
\hline
\end{tabular}

Mean values which do not share the same superscript letters are significantly different at $5 \%$ for different concentration of foaming agents.

The total phenolic content decreases as the concentration of the foaming agents' increases. In overall, the lowest total phenolic content present in the soursop powder was $266.15 \mathrm{mg}$ GAE/ $100 \mathrm{~g}$ for sample with fish gelatin at $20 \%$ of foaming agents. The percentage of the foaming agents affects the overall phenolic content in the powder. From Table 5, the phenolic content also decreases as the concentration of each foaming agents increase. Total phenolic content of the foam mat dried soursop was affected by the concentration of foaming agents but not the type of foaming agents.

\subsubsection{Color}

Colors, being one of the most significant quality parameters in dried products, have a great influence on their desirability and final price. There are many factors that affect the color of the final products such as the variety of the fruit, its ripeness and the effect of drying procedures (Viuda-Martos et al., 2012). As shown in Table 6 , the $\mathrm{L}^{*}$ represents the lightness parameter of the food products and the $\mathrm{L}^{*}$ color of all the soursop powders fall in the range of $29-35$. This value shows that the soursop powder color are less in lightness compared to the fresh fruit pulp color which has $\mathrm{L}^{*}$ value of 65.89. Color of the foam mat dried soursop powder does not affect by the type of foaming agents used in the foam mat drying process. According to Damodaran et al. (2010), the powders are less in lightness due to fruit pulps undergone enzymatic and non -enzymatic browning and become slightly dark at the end of the process due to the hot air drying process. Color value of redness $\left(\mathrm{a}^{*}\right)$ for the powders showed negative values as there is no redness in the powder as the original fruit itself in white color. Meanwhile for the value $b^{*}$, is an indicator to describe the carotenoid pigment destruction in the juice. For fresh fruit pulp, the $b^{*}$ value is 6.04 and the slight difference was observed for the foam-mat dried powders $b^{*}$ value. This shows that there is less destruction of the carotenoid pigments during the whipping of the soursop fruit pulp during the powder making process.

\subsubsection{WSI and WAI}

Even though the solubility decreases but does not decreases significantly. The solubility of soursop with fish gelatin and Arabic gum as foaming agents increases as the concentration increases as shown in Table 7. The solubility of soursop powder with fish gelatin is from 
Table 6. Color properties of the foam-mat dried powder

\begin{tabular}{ccccc}
\hline \multirow{2}{*}{ Foaming agents } & \multirow{2}{*}{ Concentration $(\%)$} & \multicolumn{3}{c}{ Color } \\
\cline { 2 - 5 } & 5 & $\mathrm{~L}^{*}$ & $\mathrm{a}^{*}$ & $\mathrm{~b}^{*}$ \\
\hline \multirow{3}{*}{ Fish gelatin } & 10 & $30.62 \pm 0.11^{\mathrm{de}}$ & $-2.46 \pm 0.03^{\mathrm{bc}}$ & $6.05 \pm 0.14^{\mathrm{cde}}$ \\
& 15 & $29.91 \pm 0.90^{\mathrm{e}}$ & $-2.25 \pm 0.10^{\mathrm{c}}$ & $5.08 \pm 0.53^{\mathrm{e}}$ \\
& 20 & $33.46 \pm 0.65^{\mathrm{bcd}}$ & $-2.42 \pm 0.06^{\mathrm{bc}}$ & $6.82 \pm 0.23^{\mathrm{bcd}}$ \\
\multirow{3}{*}{ Arabic Gum } & 2 & $32.42 \pm 0.07^{\mathrm{bc}}$ & $-2.58 \pm 0.04^{\mathrm{bc}}$ & $6.98 \pm 0.31^{\mathrm{abc}}$ \\
& 4 & $-2.61 \pm 0.11^{\mathrm{bc}}$ & $5.61 \pm 0.26^{\mathrm{de}}$ \\
& 6 & $33.70 \pm 0.27^{\mathrm{bc}}$ & $-2.58 \pm 0.28^{\mathrm{bc}}$ & $5.10 \pm 0.18^{\mathrm{e}}$ \\
& 8 & $34.04 \pm 0.08^{\mathrm{abc}}$ & $-2.78 \pm 0.12^{\mathrm{ab}}$ & $6.04 \pm 0.18^{\text {cde }}$ \\
\hline
\end{tabular}

Mean values which do not share the same superscript letters are significantly different at $5 \%$ for different concentration of foaming agents.

Table 7. Water absorption index and water solubility index of foam-mat dried soursop powder

\begin{tabular}{cccc}
\hline Foaming agents & Concentration (\%) & Water absorption index (WAI) & Water solubility index (WSI) \\
\hline \multirow{3}{*}{ Fish gelatin } & 5 & $3.26 \pm 0.34^{\mathrm{e}}$ & $41.62 \pm 1.3^{\mathrm{bcd}}$ \\
& 10 & $3.43 \pm 0.06^{\mathrm{be}}$ & $41.57 \pm 1.5^{\mathrm{bcd}}$ \\
& 15 & $3.69 \pm 0.05^{\mathrm{cd}}$ & $44.15 \pm 0.43^{\mathrm{b}}$ \\
& 20 & $4.00 \pm 0.01^{\mathrm{bc}}$ & $43.44 \pm 0.60^{\mathrm{bc}}$ \\
\hline \multirow{2}{*}{ Arabic Gum } & 2 & $4.73 \pm 0.10^{\mathrm{a}}$ & $35.95 \pm 1.8^{\mathrm{e}}$ \\
& 4 & $4.19 \pm 0.14^{\mathrm{b}}$ & $43.43 \pm 0.29^{\mathrm{bc}}$ \\
& 6 & $4.04 \pm 0.08^{\mathrm{bc}}$ & $44.51 \pm 1.2^{\mathrm{b}}$ \\
\hline
\end{tabular}

Mean values which do not share the same superscript letters are significantly different at $5 \%$ for different concentration of foaming agents.

41.62 to $43.44 \%$ and soursop powder with Arabic gum is from 35.95 to $52.54 \%$. Fish gelatin has better solubility in hot water and these properties influence the WSI of the soursop powder whereas the highest solubility shown by soursop powder with Arabic gum as a foaming agent because of Arabic gum soluble easily at room temperature. Soursop powder with Arabic gum showed higher solubility as the concentration of the Arabic gum increases.

Water absorption index is related to the capability of dry food to absorb water, and it is exactly associated with the hydration capacity (Barbosa-Canovas and Juliana, 2005). The water absorption increases as the concentration of foaming agents increase for soursop powder with fish gelatin.

\section{Conclusion}

In conclusion, foam mat drying holds a promising potential in halal food processing industry and contain high total phenolic content. Foam mat drying of soursop powder using fish gelatin at $10 \%$ concentration is recommended based on overall quality, where gelatin showed relatively a low Carr index and Hausner ratio which results in an excellent flowability, low water activity, low bulk density and tap density, and low moisture content helps to prevent the microbes and pathogen growth which can improve the shelf life of the soursop powder with high total phenolic content. Foam mat dried soursop powder can be used in many food industry applications such as instant beverages, baking, flavoring agents for confectionaries and can be used as a substitute for artificial additives.

\section{Acknowledgement}

This research was funded by Universiti Putra Malaysia under Putra Grant IPS with Project No. GP IPS/2017/9517100.

\section{References}

Abbasi, E. and Azizpour, M. (2016). Evaluation of physicochemical properties of foam mat dried sour cherry powder. LWT-Food Science and Technology, 68, 105-110. https://doi.org/10.1016/ j.lwt.2015.12.004

Adewole, S.O. and Caxton-Martins, E.A. (2006). Morphological changes and hypoglycemic effects of Annona muricata Linn. (Annonaceae) leaf aqueous extract on pancreatic B-cells of streptozotocintreated diabetic rats. African Journal of Biomedical Research, 9, 173-187. https://doi.org/10.4314/ ajbr.v9i3.48903

Barbosa-Canovas, G.V. and Juliano, P. (2005). Physical and chemical properties of food powders. In Onwulata, C. (Ed.) Encapsulated and powdered 
foods., p. 39 - 71. Boca Raton: Taylor and Francis. https://doi.org/10.1201/9781420028300.ch3

Baskar, R., Rajeswari, V. and Kumar, T.S. (2009). In vitro antioxidant studies in leaves of Annona species. Indian Journal of Experimental Biology, 45(5), 480485.

Belitz, H.D., Grosh, W., and Schieberle, P. (Ed.). (2009). Food Chemistry. 4th ed. Berlin: Springer.

Berk, Z. (2009). Food process engineering and technology. 1st ed. New York: Academic Press. https://doi.org/10.1016/B978-0-12-373660-4.000284

Chang, K.S., Kim, D.W., Kim, S.S. and Jung, M.Y. (2009). Bulk Flow Properties of Model Food Powder at Different Water Activity. International Journal of Food Properties, 1(1), 45-55. https:// doi.org/10.1080/10942919809524564

Damodaran, S., Parkin, K.L. and Fennema, O.R. (2010). Fennema's food chemistry. 4th ed. London: CRC Press.

Dickinson, E. (1992). Introduction to Food Colloids. UK: Oxford University Press,

Falade, K.O, Adeyanju, K. and Uzo-Peters, P. (2003). Foam-mat drying of cowpea (Vigna unguiculata) using glyceryl monostearate and egg albumin as foaming agents. European Food Research and Technology, 217, 486-491. https://doi.org/10.1007/ s00217-003-0775-3

Falade, K.O. and Solademi, O.J. (2010). Modelling of air drying of fresh and blanched sweet potato slices. International Journal of Food Science and Technology, 45(2), 278-288. https://doi.org/10.1111/ j.1365-2621.2009.02133.x

Febrianto, A., Kumalaningsih, S. and Aswari, A.W. (2012). Process Engineering of Drying Milk Powder with Foam-Mat Drying Method. A Study on the Effect of the Concentration and Types of Filler Process. Journal of Basic and Applied Scientific Research, 2(4), 3588, 3589, 3591.

Fumagalli, F. and Silveira, A.M. (2005). Quality evaluation of microwave-dried Packham's triumph pear. Drying Technology, 23(9-11), 2215-2226. https://doi.org/10.1080/07373930500212701

Jaya, S. and Das, H. (2004). Effect of maltodextrin, glycerol monostearate and tricalcium phosphate on vacuum dried mango powder properties. Journal of Food Engineering, 63(2), 125-134. https:// doi.org/10.1016/S0260-8774(03)00135-3

Johanson, K. (2005). Powder flow properties. In Onwulata, C. (Ed.) Encapsulation and powdered foods., p. 331-361. Boca Raton: CRC Press

Kandasamy, P., Varadharaju, N., Kalemullah, S. and
Moitra, R. (2012). Production of papaya powder under foam-mat drying using methylcellulose as foaming agent. Asian Journal of Food and Agro-Industry, 5(5), 374-384

Karim, A.A. and Wai, C.C. (1999). Foam mat drying of star fruit (Averrhoa carambola L.) puree. Stability and air drying characteristics. Food Chemistry, 64 (3), 337-210. https://doi.org/10.1016/S0308-8146 (98)00119-8

Kudra, T. and Ratti, C. (2006). Foam-mat drying: Energy and cost analyses. Canadian Biosystems Engineering, 48, 28-32

Morgan, A., Graham, R., Ginnette, L. and Williams, G. (1961). Recent developments in foam-mat drying. Food Technology, 15, 37-39.

Mortensen, A., Aguilar, F., Crebelli, R., Di Domenico, A., Frutos, M.J., Galtier, P., Gott, D., GundertRemy, U., Lambré, C., Leblanc, J-C., Lindtner, O., Moldeus, P., Mosesso, P., Oskarsson, A., ParentMassin, D., Stankovic, I., Waalkens-Berendsen, I., Woutersen, R.A., Wright, M., Younes, M., Brimer, L., Christodoulidou, A., Lodi, F., Tard, A. and Dusemund, B. (2017). Scientific Opinion on the reevaluation of acacia gum (E 414) as a food additive. EFSA Journal, 15(4), e04741. https:// doi.org/10.2903/j.efsa.2017.4741

Nelson, D.L. and Cox, M.M. (2004). Lehninger Principles of Biochemistry. 4th ed. Retrieved from website: http://bcs.whfreeman.com/lehninger/ default.asp

Rao, M.A., Rizvi, S.S.H. and Datta, A.K. (2005). Engineering properties of foods. 3rd ed. Boca Raton: CRC Press.

Sangamithra, A., Sivakumar, V., Swamy, G.J. and Kannan, K. (2014). Foam mat drying of food materials: A review. Journal of Food Processing and Preservation, 39(6), 3165-3174. https:// doi.org/10.1111/jfpp.12421

Thuwapanichayanan, R., Prachayawarakorn, S. and Soponronnarit, S. (2008). Drying characteristics and quality of banana foam mat. Journal of Food Engineering, 86(4), 573-583. https:// doi.org/10.1016/j.jfoodeng.2007.11.008

Viuda-Martos, M., Ruiz-Navajas, Y., Martin-Sanchez, A., Sanchez-Zapata, E., Fernandez-Lopez, J., Sendra, E., Sayas-Barbera, E., Navarro, C. and Perez -Alvarez, J.A. (2012). Chemical, physio-chemical and functional properties of pomegranate (Punica granatum L.) bagasses powder coproduct. Journal of Food Engineering, 110(2), 220-224. https:// doi.org/10.1016/j.jfoodeng.2011.05.029 